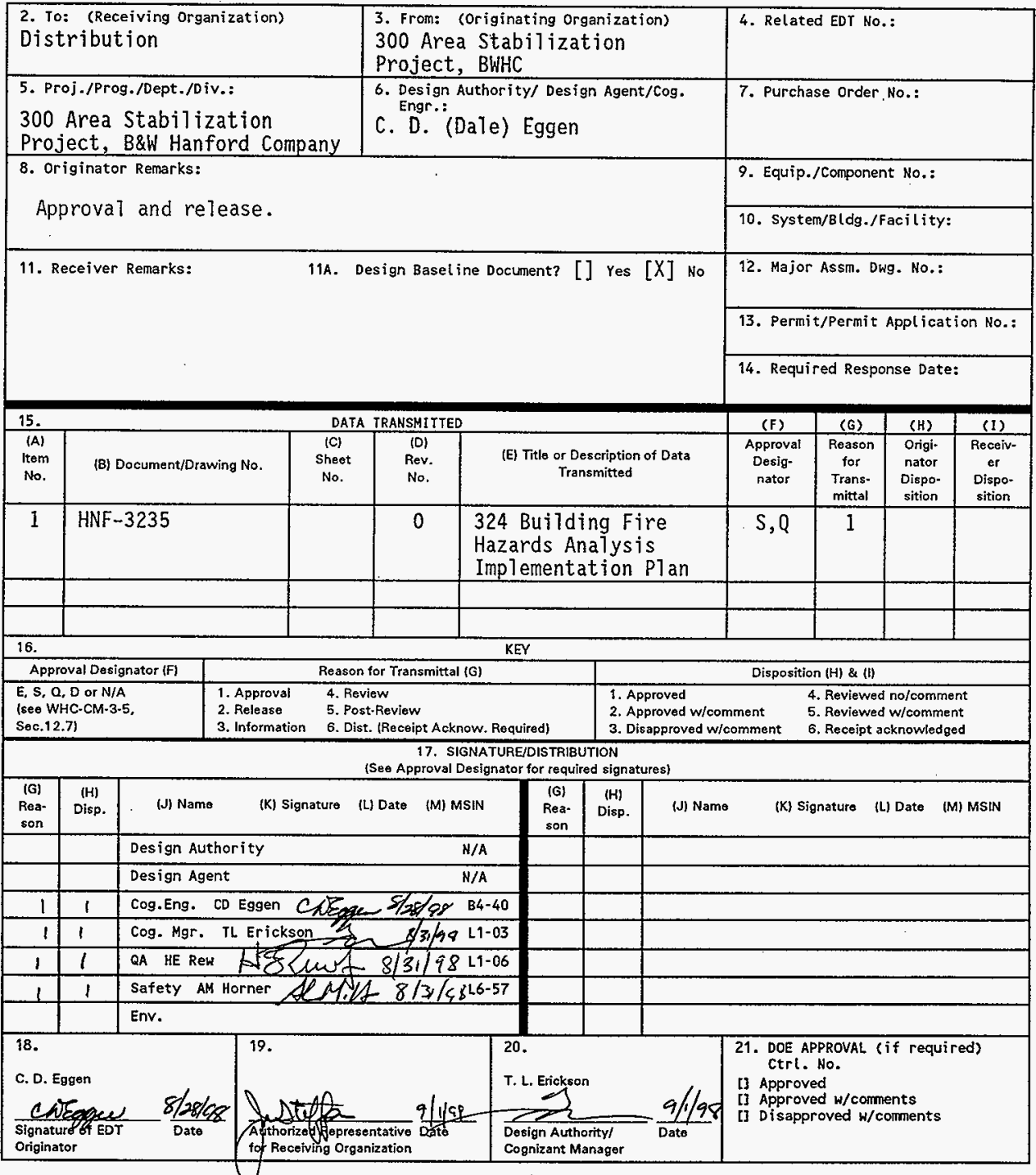


HNF-3235, Rev. 0

\title{
324 Building Fire Hazards Analysis Implementation Plan
}

\author{
C. D. Eggen
}

B\&W Hanford Company, Richland, WA 99352

U.S. Department of Energy Contract DE -ACO6-96RL13200

EDT/ECN: 623093

UC: 2050

Org Code: 19210

Charge Code: HAN98200/K4MI 1

B\&R Code: EW7002010

Total Pages: 16

Key Words: 324 Building, Fire Hazards, Analysis, Implementation Plan

Abstract: BWHC will use this Implementation Plan to bring the 324 Building into compliance with DOE Order 5480.7A and RLID 5480.7.

TRADEMARK DISCLAIMER. Reference herein to any specific comercial product, process, or service by trade name, trademark, manufacturer, or otherwise, does not necessarily constitute or imply its endorsement, recommendation, or favoring by the United States Government or any agency thereof or its contractors or subcontractors.

Printed in the United States of America. To obtain copies of this document, contact: Document Control Services, P.0. Box 950, Mailstop H6-08, Richland WA 99352, Phone (509) 372-2420; Fax (509) 376-4989.
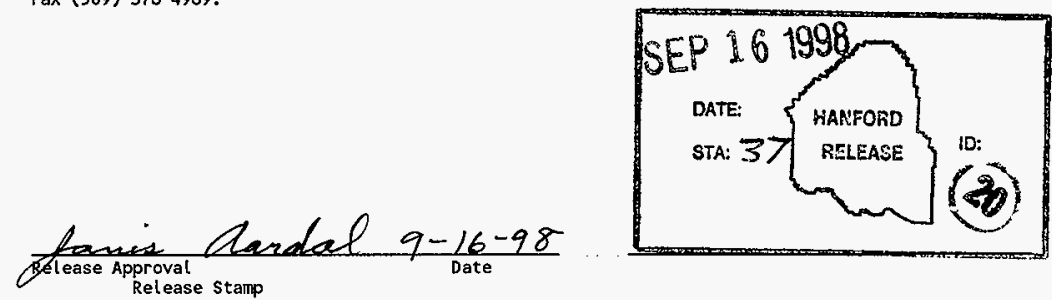
HNF-3235, Rev. 0

\section{Building Fire Hazards Analysis Implementation Plan}

August 1998

prepared for:

United States Department of Energy, Richland Operation Office Richland, Washington

prepared by:

B\&W Hanford Company 
HNF-3235, Rev. 0

\section{EXECUTIVE SUMMARY}

In March 1998, the 324 Building Fire Hazards Analysis (FHA) (Reference 1) was approved by the U.S. Department of Energy, Richland Operations Office (DOE-RL) for implementation by B\&W Hanford Company (BWHC). The purpose of the FHA was to identify gaps in compliance with DOE Order 5480.7A (Reference 2) and Richland Operations Office Implementation Directive (RLID) 5480.7 (Reference 3), especially in regard to loss limitation. The FHA identified compliance gaps in six areas and provided 20 recommendations to bring the 324 Building into compliance with DOE Order 5480.7A. Additionally, one observation was provided. To date, four of the recommendations and the one observation have been completed. Actions identified for seven of the recommendations are currently in progress. Exemption requests will be transmitted to DOE-RL for three of the recommendations. Six of the recommendations are related to future shut down activities of the facility and the corrective actions are not being addressed as part of this plan.

The actions for recommendations associated with the safety related part of the 324 Building and operation of the cells and support areas were evaluated using the Unreviewed Safety Question (USQ) process. Major Life Safety Code concerns have been corrected. The status of the recommendations and actions was confirmed during the July 1998 Fire Protection Assessment.

BWHC will use this Implementation Plan to bring the 324 Building and its operation into compliance with DOE Order 5480.7A and RLID 5480.7. 
HNF-3235, Rev. 0

\section{TABLE OF CONTENTS}

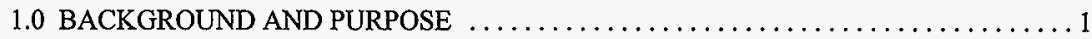

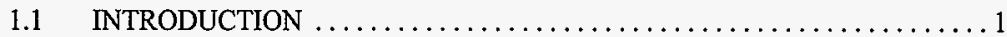

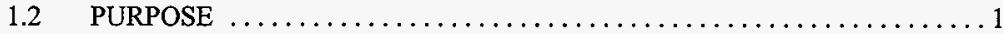

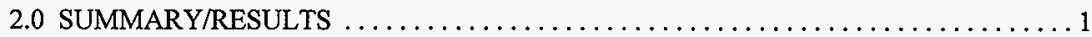

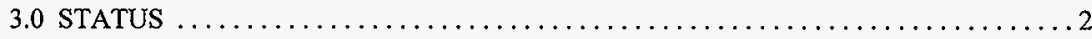

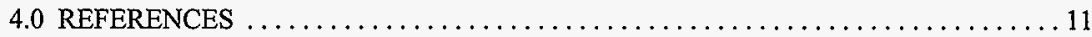

\section{LIST OF TABLES}

5-26 - Maximum Quantities of a Single Combustible Material $\ldots \ldots \ldots \ldots \ldots \ldots \ldots$

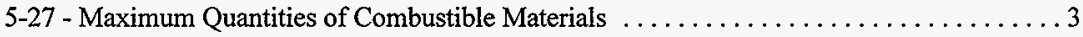


HNF-3235, Rev. 0

\section{TERMS}

BWHC

D\&D

DOE

DOE-RL

ECN

ERC

FHA

FPE

FSM

HEPA

HFD

JCS

MPFL

NFPA

PNNL

PRC

REC

RFAR

RLID

ROM

SAR

SMF

UL

USQ
B\&W Hanford Company

Decontamination and Decommissioning

U.S.Department of Energy

U.S. Department of Energy, Richland Operations Office

Engineering Change Notice

Environmental Restoration Contractor

Fire Hazards Analysis

Fire Protection Engineer

Fire Systems Maintenance

High-Efficiency Particulate Air

Hanford Fire Department

Job Control System

Maximum Possible Fire Loss

National Fire Protection Association

Pacific Northwest National Laboratory

Plant Review Committee

Radiochemical Engineering Cells

Radio Fire Alarm Signal

Richland Operations Office Implementation Directive

Rough Order of Magnitude

Safety Analysis Report

Shielded Materials Facility

Underwriter's Laboratories

Unreviewed Safety Question 


\section{BUILDING FIRE HAZARDS ANALYSIS IMPLEMENTATION PLAN}

\subsection{BACKGROUND AND PURPOSE}

\subsection{INTRODUCTION}

This report addresses corrective measures taken to implement the recommendations contained in the 324 Building Fire Hazards Analysis (FHA) (Reference 1). The FHA was performed by Hughes Associates, Inc., in September 1997. The FHA was based on U.S. Department of Energy (DOE) Order 5480.7A, "Fire Protection" (Ref. 2), and Richland Operations Office Implementation Directive (RLID) 5480.7, "Fire Protection" (Ref. 3). This Implementation Plan provides a summary of the FHA recommendations and actions.

\subsection{PURPOSE}

The FHA was performed to analyze the loss potential of an accident in accordance with the guidelines contained in DOE Order 5480.7A and RLID 5480.7. The order and directive contain guidelines that are required to be reviewed. In addition, the order and directive require compliance with certain national codes and standards, such as the National Fire Protection Association (NFPA). The FHA documents the status of the facility at meeting the guidelines, codes, and standards, and provides recommendations to bring the facility into compliance.

This Implementation Plan addresses BWHC's actions associated with each FHA recommendation/observation to bring the 324 Building into compliance with DOE Order 5480.7A and RLID 5480.7

\subsection{SUMMARY/RESULTS}

The FHA performed by Hughes Associates, Inc., was a comprehensive review of this facility as it was being transferred from operation and control of Pacific Northwest National Laboratory (PNNL) to BWHC.

The FHA for the 324 Building included 20 recommendations and one observation. Fourteen recommendations and the one observation are associated with facility operations. Six of the recommendations are related to the future shut down activities of the facility. This plan outlines $\mathrm{BWHC}$ 's actions for addressing the FHA recommendations. 
HNF-3235, Rev. 0

\subsection{STATUS}

The recommendations are shown as they appear in the FHA (Reference 1) followed by the actions planned or completed for each recommendation.

\section{REC 4-1}

During the walkdown, it was observed that the suspended ceiling in Room 115 (presently used for storage) has been removed. Consequently, the pendent sprinklers are located approximately 2 feet below the true ceiling. To ensure the effectiveness of the sprinkler system, the suspended ceiling should be reinstalled or the sprinklers should be relocated to within 12 inches of the true ceiling as required by NFPA 13, Article 4-6.4.1.

A walkdown of the room was performed as the part of July 1998 Fire Protection Assessment and it was verified that the ceiling had not been replaced. Fire System Maintenance will rotate the fitting and install new upright heads on new risers in this room. Fire System Maintenance Job Control System (JCS) Work Package 2G-98-9157/M was generated to perform this work. An Engineering Change Notice (ECN) will be prepared to correct drawing H-3-27926 for changing the heads from pendent to upright. The associated JCS package will be planned, scheduled, and worked.

\section{REC 4-2}

The monthly "front button" test of the radio fire alarm signal (RFAR) box as stipulated by HNF-PRO-351, Project Hanford Policy and Procedure System, system testing/inspecting and maintenance is not being conducted at Building 324 or throughout the site. Implementation of this test procedure, or formal disposition of why implementation is not required is recommended.

This testing is being performed in accordance with Fire System Maintenance (FSM) Procedure FS0003, Revision 0 / Change B. A review of the records for the RFAR front button test was conducted by a qualified Fire Protection Engineer (FPE). The records indicate that this test is being performed as required by HNF-PRO-351, Table 2. This recommendation is completed.

\section{REC 5-1}

As part of compliance with DOE Order 5480.7A, Section 9.b. (3)(b), administrative controls to restrict the total quantity and type of combustibles that can be in a particular cell or airlock shall be implemented. For B-Cell, the Radiochemical Engineering Cell (REC) airlock, South Cell, East Cell, and the Shielded Materials Facility (SMF) airlock, areas where flashover is not expected to occur, the quantity of any single combustible material should be no greater than the quantities listed in Table 5-26 below: 
HNF-3235, Rev. 0

Table 5-26 - Maximum Quantities of a Single Combustible Material

\begin{tabular}{|c|c|}
\hline $\begin{array}{c}\text { Cellulose Material } \\
\text { (wood, paper, cloth) } \\
\text { (kg) }\end{array}$ & $\begin{array}{c}\text { Plastics } \\
\text { (kg) }\end{array}$ \\
\hline $\mathbf{5 4 0}$ & 100 \\
\hline
\end{tabular}

This recommendation will be accomplished by the institution of a combustible control program for the cells. Procedure SOP-REC-G-22 for the control of combustibles has been established in $\mathrm{B}$ Cell and is being extended to the SMF Cell. Combustible control procedures are being extended to other cells and airlocks in the 324 Building. This procedure limits the quantities of combustibles that can be in areas that are not provided with automatic sprinkler protection. In addition, controls have been placed on spark producing sources. The combustible control program in B Cell has been in place for more than six months. Operations has the responsibility for the program, however, an FPE reviews the inventory and program at least monthly. Completion of changes to Procedure SOP-REC-G-22 to cover all of the cells and airlocks will close this recommendation.

\section{REC 5-2}

As part of compliance with DOE Order 5480.7A, Section 9.b.(3)(b) for cells where flashover can occur, the maximum quantity of mixed combustible materials shall not exceed the values listed in Table 5-27 below.

Table 5-27 - Maximum Quantities of Combustible Materials

\begin{tabular}{|c|c|c|}
\hline $\begin{array}{c}\text { Cell } \\
\text { Identification }\end{array}$ & $\begin{array}{c}\text { Cellulose Material } \\
\text { (wood, paper, cloth) } \\
\text { (kg) }\end{array}$ & $\begin{array}{c}\text { Plastics } \\
\text { (kg) }\end{array}$ \\
\hline A & 59 & 22 \\
\hline C & 35 & 13 \\
\hline D & 43 & 16 \\
\hline
\end{tabular}

See the action for REC 5-1 above.

REC 5-3

As part of compliance with DOE Order 5480.7A, Section 9.b. (3)(b), in order to preclude a fire in a hot cell from involving mineral oil from a failed hot cell window, quantities of combustible materials shall be limited to $18 \mathrm{lbs}(8.4 \mathrm{~kg})$ with $3 \mathrm{ft}$ $(0.91 \mathrm{~m})$ from the surface of any hot cell shield window. 
HNF-3235, Rev. 0

The loading is reviewed monthly by the FPE and is currently less than $8.4 \mathrm{~kg}$ for B Cell; therefore, B Cell is in compliance. Compliance with the combustible loading limit in the remaining cells will complete this recommendation. This will be accomplished with the procedure revision noted in Rec 5-1.

\section{REC 5-4}

In order to prevent a flammable/combustible liquid fire in the truck lock area for exposing and potentially causing structural column failure and resulting in a breach of confinement, the three exposed steel columns shall be coated or protected in accordance with the requirements for a 2-hour fire-rated assembly. Implementation of this recommendation ensures that LCO 2.1, Exhaust System High-Efficiency Particulate Air (HEPA) Filtration, is maintained during the fire condition and serves to satisfy DOE 5480.7A, Section 9.b.(12).

The loss potential for the lack of column protection is estimated at $\$ 200,000$. Column protection would include fire barrier material that is listed by Underwrites Laboratories (UL) or approved by Factory Mutual (FM). Column protection costs could approach $\$ 55,000$ a column or about $\$ 165,000$ for the three columns in the truck bay. Based on a projected life for the 324 Building of eight years and the cost to protect the columns compared to the loss potential being of the same Rough Order of Magnitude (ROM) cost, this condition should be accepted for the remaining life of the facility. An exemption request will be prepared by BWHC and transmitted to DOE-RL.

REC 5-5

(1) Consistent with HNF-PRO-359, Section 2.3 , ensure only that only noncombustible insulating materials are placed in direct contact with heat generating sources.

(2) In accordance with HNF-PRO-359, Section 2.3, ensure that combustible waste is collected only in metal containers provided with lids.

(3) Perform documented monthly housekeeping inspections as required by HNF-PRO-368, Project Hanford Policy and Procedure System for Laboratories.

Monthly housekeeping inspections are conducted in this facility in accordance with HNF-IP-1264, Section 1.4. The housekeeping procedure uses HNF-PRO-359 and HNF-PRO-368 as a basis for the inspection requirements. Housekeeping was found to be acceptable throughout the 324 Building during the recently completed Fire Protection Assessment.

During the FHA inspection, many storage areas were noted to contain unacceptable quantities of combustible materials. The changes to the HNF-IP-1264 and its implementation has improved the housekeeping throughout the facility. The facility is currently in compliance with the above HNF-PROs and facility procedures. Therefore, this recommendation has been completed. 
HNF-3235, Rev. 0

REC 5-6

Eliminate the practice of storing bagged low level combustible waste materials on the floor or in open plastic material containers in Radiological Support Area, Room 147. In accordance with HNF-PRO-359, Section 2.3, ensure that low level waste materials awaiting compaction are only collected and stored in metal containers provided with lids.

Waste materials were previously allowed to accumulate in Room 147 as noted in the FHA inspection. Currently, combustible materials are not allowed to accumulate in Room 147. Waste is removed as soon as possible. Housekeeping was found to be acceptable during the July 1998 Fire Protection Assessment. This recommendation has been completed.

REC 5-7

RLID 5480.7, Section 8.2.c, stipulates that the level of fire protection for nuclear facility final exhaust/confinement HEPA filter shall be determined using the Filter Plenum Fire Protection Criteria contained in the DOE Fire Protection Resource Manual. The DOE Filter Plenum Fire Protection Standard, Section 8.2, stipulates fire screens must be located upstream of the final filter plenum in order to stop burning embers from reaching the final exhaust filters. Based on consultation with cognizant building personnel, the Zone I and Zone II HEPA filters are not provided with fire screens. Since burning embers could result in a HEPA filter fire, installation of fire screens is required.

The cost to provide fire screens is high due to the locations, contamination levels, etc. PNNL Engineering Request No. 4082 was started in 1992 and PNNL Project D-326 was subsequently initiated in 1993 to address the addition of fire screens in the ducts. Project D-326 was never funded, so cost estimates are not available. If the screens are installed, the project design will need to accommodate for lint buildup, cleaning of screens, reduced airflows, and higher differential pressures.

The recently completed FHA derived limited benefits from installation of fire screen in the ducts. The 324 Building Safety Analysis Report (SAR) does not take credit for the fire screens in its accident scenario. The cells are operated in accordance with strict administrative controls which reduces the chance of a fire. Since the capital cost of installing fire screens outweighs the benefits derived, an exemption request will be transmitted to DOE-RL to eliminate the requirement for having fire screens upstream of the final filter plenum.

\section{REC 7-1}

Completion of the corrective action for each of the deficiencies cited below to comply with the applicable NFPA 101 requirement is required. 
HNF-3235, Rev. 0

Stair \#6

- $\quad$ Room \#20, the elevator machine room, opens directly into the exit stair at basement level. The room contains a reservoir for combustible hydraulic fluid. This configuration is prohibited by NFPA 101, Article 5-1.3. Of particular concern is the potential for a fire involving the fluid to spread to the stair, filling it with it products of combustion and making the stair untenable. To limit this potential, construction of a dike within the room designed to contain a fluid spill within the confines of the room is recommended.

- The door serving Room \#21, basement level does not latch as required by NFPA 101, Article 5-2.1.7.1. Repair/replacement of the existing hardware is required.

- The pair of double doors serving Room \#18 are not equipped with automatic closures as required by NFPA 101, Article 5-2.1.8. Installation/replacement of automatic closures is required.

A walkdown of the doors into Rooms 18, 20, and 21 was completed during the July 1998 Fire Protection Assessment. The doors to Rooms 18 and 21 have been repaired (Work Package 3I-97-00842). Work Package 3I-98-064 (installation of the curb in Room 20) is currently in planning. Completion of this work package for the curb in Room 20 will close out this recommendation.

\section{Stair \#2}

- The basement level of stair \#2 contains two dry-type transformers. This configuration is prohibited by NFPA 101, Articles 5-1.2 and 5-1.3.1. Of particular concern is the potential for the equipment to overheat, generate products of combustion and make the stair untenable. Removal of this equipment is required. Alternatively, separate this equipment from the stair by 2 -hour fire-rated construction.

The basement level of Stair 2 contains two dry-type transformers as noted in the FHA. Additionally, a third transformer is located on the third floor. The concern can be corrected in one of two ways. The first option is to relocate the transformers, wiring, and related equipment to another location. This has an estimated cost of $\$ 400,000$ to complete. The other option is to enclose the transformers in a two-hour fire-rated enclosure. For the basement level transformers, this has an estimated cost of $\$ 25,000$ for the enclosure and about $\$ 50,000$ to provide a new cooling source for the transformers. However, the transformer on the third floor must be relocated due to the limited available space. The relocation cost is estimated to be about $\$ 50,000$. This corrective action will be accomplished via a capitally funded project that will identify the best option. 
HNF-3235, Rev. 0

- The first floor stair $\# 2$ door adjoining corridor 11 is not fire-rated, non-latching and contains a plastic viewing panel. Replacement of the non-rated door with a $1 \frac{1}{2}$ fire-rated assembly is required. Recommendation has been completed.

- The third floor stair \#2 door serving equipment Room 317 is firerated but has had the hardware removed. Reinstallation of latching hardware is required. Recommendation has been completed.

A walkdown of the two doors in question was performed as part of the July 1998 Fire Protection Assessment. The two doors were repaired or replaced (Work Package 31-97-00842). This Work Package closes out the recommendation for the doors on the second and third floors.

\section{Stair \#8}

- The third floor landing of stair \#8 contains a hand and foot monitor no longer in service. This is prohibited by NFPA 101, Article 5-1.3.4. Removal of the hand and foot monitor is required.

Work Package 3I-97-00842 has been planned for the removal of the hand and foot counter. Upon completion of this work, this item will be closed.

REC 10-1

To comply with DOE Order 5480.7A, Section 9.b.(4)(b), ensure that the Zone I and Zone II exhaust ventilation systems are not capable of producing a $\triangle P$ across the HEPA filters $\geq 2.5 \mathrm{kPa}$ (10 inches of water or more).

The report, "Completion of USQ Evaluation Closure of 324-BWHC-97-005, 324 Building Zone 1," documented the completion of Work Package 3I-97-00823. This work package modified belts/sheaves to lower the fan static pressure from 17 inches of water to less than 10 inches of water. This action closes out this recommendation.

REC 10-2

As part of compliance with DOE Order 5480.7A, Section 9.b.(3)(b), and as required by Section 8.i.(7), submit an equivalency request to DOE-RL requesting exclusion of sprinkler or other automatic fire protection from the hot cell areas. The equivalency request is considered justified based on the analysis contained in the FHA and the implementation of recommendations 5-1, 5-2, 5-3, and 10-1 above.

An exemption request, rather than an equivalency request, will be prepared by $\mathrm{BWHC}$ and transmitted to DOE-RL. This exemption will be justified based on the 324 Building FHA recommendation above. 
HNF-3235, Rev. 0

REC 10-3

It is concluded that there are two potentially significant discrepancies between the SAR's "Major Fire" scenario and the FHA's MPFL:

(1) The ground release postulated by the SAR vs. the stack release postulated by the FHA; and

(2) The assumption and conditions necessary for each event to occur. The SAR defines the frequency of the Major Fire as "extremely unlikely." Although, the FHA does not assign frequency, it concludes that a fire involving a relatively small quantity of combustibles $(8.4 \mathrm{~kg})$ in a hot cell and located in close proximity to a hot cell shield window can lead to consequences consistent with the "Major Fire" postulated by the SAR and comparable with the MPFL event. Further, this scenario is not dependent on the primary assumptions cited by the SAR for placing the "Major Fire" in the "extremely unlikely" category. Since fires in hot cells are expected, it appears that the frequency of this FHA fire scenario could be greater than "extremely unlikely" and have consequences consistent with the "Major Fire."

Consistent with the guidance given in WHC-SD-GN-FHA-30001, Integration of Fire Hazards Analysis and Safety Analysis Report Requirements, these discrepancies warrant further evaluation to determine the potential impact to the building's authorization basis.

The ground release scenario described in the SAR is more conservative in terms of dose consequences than a stack release and, as such, is the bounding analyzed accident in the SAR. A stack release disperses material more and therefore increases cleanup cost and is the bounding release for the FHA. However, accidents in the SAR were reviewed as a result of the FHA and it was determined that the assumptions of the localized fire in the SAR were in question. A USQ evaluation concluded that a potential for the fans to fail the plugged HEPA filters by breach existed. A USQ was declared. The fan speed was reduced to eliminate the potential for the fans to breach the filters. This placed the facility within the assumptions of the SAR. USQ evaluation "324 Building Zone 1 Fan Modification," 324-BWHC-97-017, concluded that the facility was again operating in accordance with SAR assumptions. This evaluation will be incorporated into the SAR in the annual update.

The major fire probability of the SAR was brought into question. A USQ screening indicated that, based on a lack of information, a USQ could not be dismissed. A probabilistic analysis was performed ("324 Building B Cell Fire Analysis," HNF-1637, Rev. 0) to evaluate the probability of a major fire in B Cell. USQ evaluation "324 Major Fire Probability Resolution for B Cell," 324-BWHC-97-017, was performed. On November 26, 1997, the Plant Review Committee (PRC) concurred with the USQ evaluation and concluded that a USQ did not exist. The probabilistic analysis was extrapolated from and extended to cover the other hot cells in the USQ evaluation, "324 Major Fire Probability REC and SMF Hot Cells," 324-BWHC-98-055. The 
HNF-3235, Rev. 0

PRC reviewed the USQ evaluation and concluded on June 22, 1998, that a USQ did not exist for other hot cells. The definition of Best Protected Class of Fire Protection was revised in the fire protection program. The results of the above evaluations will be incorporated into the SAR during the annual update.

The conclusion, reached by the FHA and the SAR, is that the loss potential for the 324 Building is less than the limits specified in DOE Order 5480.7A. The USQ process above closes out this recommendation.

REC 11-1

The Hanford Fire Department has prepared a pre-fire plan. The pre-fire plan was last updated December 1995. It is scheduled for revision and update in 1998. Per the Hanford Site Fire Department Needs Assessment [Westinghouse Hanford Company, 1996], updating of pre-fire plans for in-use facilities having a replacement cost value equal to or greater than $\$ 50$ million is required annually. The current replacement costs of the Building 324 is estimated at $\$ 48,065,140$ and total content replacement costs at $\$ 2,946,797$, for a combined value of in excess of $\$ 50$ million. Also, given the potential for a fire with significant fire loss, annual revision and update of the pre-fire plan is recommended.

The 324 Building Pre-Fire Plan is scheduled to be updated by the Hanford Fire Department (HFD) during December 1998. Subsequent to the December 1998 update, the prefire plan will be updated annually. Upon completion of the December 1998 update, this item will be closed.

\section{FIRE PROTECTION FEATURES RELATIVE TO DECOMMISSION AND DEMOLITION ACTIVITIES}

REC 18-1

For mixed use conditions, the building fire alarm system must be maintained as long as the conditions cited by NFPA 101, Article 5-2.1.1.3 apply. At some point, during the decommission and demolition activity process, should the building fire alarm system must be maintained as long as the conditions cited by NFPA 101, Article 28-3.4.1 apply.

Recommendations 18-1 through 18-6 are applicable to the facility during the future decontamination and decommissioning (D\&D) activities. These recommendations will be applicable when the building is turned over from Facility Transition Operations to the Hanford Site's Environmental Restoration Contractor (ERC). Therefore, these recommendations will not be addressed at this time.

\section{REC 18-2}

To comply with DOE Order 5480.7A, Section 9.b.(3)(b), and consistent with RLID 5480.7, Section 8.3a, the fire protection water supply to the building fire 
protection systems as well as the hydrants must be maintained as long as the fire loss potential exceeds $\$ 1$ million.

See REC 18-1.

REC 18-3

The REC and SMF cells and airlocks are protected with manual deluge fire suppression and in the case of the SMF South cell, a dry chemical fire extinguisher manifold to enable the manual discharge of a fire extinguisher from the gallery side. The FHA indicates that a relatively small fire could cause damage to a hot cell shield window and result in a mineral oil fire which clogs the HEPA filters. Under worst case conditions, an uncontrolled release of radiological materials is postulated. Consistent with RLID 5480.7 criteria, these manual suppression systems must be maintained until the radiological materials within the REC and SMF cells and airlocks are removed.

See REC 18-1.

REC 18-4

A reduction in the number of extinguishers that are maintained may be appropriate at some point during $D \& D$. This reduction should be reviewed and approved by the cognizant fire protection engineer.

See REC 18-1.

REC 18-5

Consistent with the criteria for occupancy cited in NFPA 101, Article 5-2.1.1.3, and RLID 5480.7, Section 8.3.c, maintain fire rated stair enclosures until building occupancy is limited to no more than 10 people.

See REC 18-1.

REC 18-6

The fire rated partitions separating the office addition and the high bay addition from the original Building $\mathbf{3 2 4}$ reduce the potential monetary loss due to fire but are not required for life safety. Consistent with RLID 5480.7, Section 8.3.b, to limit the fire risk associated with radiological material release, maintaining these fire rated partitions until the radiological materials are removed is recommended.

See REC 18-1. 
HNF-3235, Rev. 0

\section{OBSERVATIONS}

Observations address issues which are not mandatory to comply with mandatory fire protection criteria, but are considered to be consistent with the requirements for the best protected class of industrial risks cited by DOE Order 5480.7A, Section 9.

\section{Exposure Fire Potential}

\section{Observation 17-1}

The only exposure identified within $6 \mathrm{~m}(20 \mathrm{ft})$ of the building is a trailer located approximately 10 feet from the north side of the Building 324 office addition. Removal/ relocation of the trailer away from Building 324 (at least 20 feet) is recommended.

The trailer has been removed. The recommended action for this observation is complete.

\subsection{REFERENCES}

1. Hughes Associates, Inc., "324 Building Fire Hazards Analysis," HNF-SD-HT-FHA-200, Rev. 0, dated September 1997.

2. U.S. Department of Energy (DOE) Order 5480.7A, "Fire Protection."

3. Richland Operations Office Implementation Directive (RLID) 5480.7, "Fire Protection."

4. National Fire Protection Association (NFPA) 13, "Installation of Sprinkler Systems."

5. NFPA 101, "Life Safety Code." 


\begin{tabular}{|c|c|c|c|c|c|c|}
\hline \multicolumn{7}{|c|}{ DISTRIBUTION SHEET } \\
\hline \multirow{2}{*}{$\begin{array}{l}\text { To } \\
\text { Distribution }\end{array}$} & \multirow{2}{*}{$\begin{array}{l}\text { From } \\
300 \mathrm{~A}\end{array}$} & \multirow{2}{*}{\multicolumn{3}{|c|}{ Stabilization Proj: }} & \multicolumn{2}{|c|}{ Page 1 of 1} \\
\hline & & & & & \multicolumn{2}{|c|}{ Date $08 / 17 / 98$} \\
\hline \multicolumn{5}{|c|}{ Project Title/Work Order } & \multicolumn{2}{|c|}{ EDT No. 623093} \\
\hline \multicolumn{5}{|c|}{324 Building Fire Hazards Analysis Implementation Plan } & \multicolumn{2}{|c|}{ ECN No. } \\
\hline Name & & MSIN & $\begin{array}{c}\text { Text } \\
\text { With All } \\
\text { Attach. }\end{array}$ & Text Only & $\begin{array}{l}\text { Attach./ } \\
\text { Appendix } \\
\text { Only }\end{array}$ & $\begin{array}{c}\text { EDT/ECN } \\
\text { Only }\end{array}$ \\
\hline CD Eggen & & B4-40 & $x$ & & & \\
\hline TL Erickson & & L] -03 & $x$ & & & \\
\hline AM Horner & & L6-57 & $x$ & & & \\
\hline HE Rew & & L]-06 & $x$ & & & \\
\hline RS Spencer. & & L1-05 & $x$ & & & \\
\hline JM Steffen & & $N 1-47$ & $x$ & & & \\
\hline Central Files & & $B 1-07$ & $x$ & & & \\
\hline
\end{tabular}

